\title{
Impacts of Climate change on Hydropower Potential in Kaligandaki River Basin -A Case Study of Kaligandaki Gorge Hydropower Project, North of Nepal
}

\author{
Lekha N Bagale* \\ Divisional Hydrologist, India
}

Submission: May 26, 2017; Published: July 31, 2017

*Corresponding author: Lekha N Bagale, Divisional Hydrologist, Ministry of Energy, Singhdurbar, Kathmandu, Nepal,India

Email: Inbagale@gmail.com

Abstract

Nepal has a considerable hydropower potentiality, however the analysis of Kaligandaki River Basin optimization of power potentiality and subsequently identified two critical impacts of climate change-GLOF's and variability of runoff along with temperature difference are most pronounced during the dry winter season, and least during the height of the monsoon. In Himalaya region the Intergovernmental Panel on Climate Change (IPCC) has indicated that global warming is occurring relatively faster in recent decades, with the rate of temperature increase being greater in the high altitude Himalaya, then lowland parts of Nepal [1].

It is more susceptible to impacts of climate change than a reservoir based hydro installation, on meteorological data obtained from Lete station, near a hydropower project site (Kaligandaki Gorge Hydropower), precipitation patterns slightly increase of $0.28 \mathrm{~mm}$, however overall steeply decreasing trend at Jomsom station.

This study reveals the optimization of power potentiality at Kaligandaki River Basin and impacts of Climate change in Kaligandaki George Hydropower projects a case study. In this basin, power potentiality area some hydropower station and their energy production fluctuations over the season reflect the climate change impacts to the hydropower production in Nepal as a whole.

Keywords: Kaligandaki climate change decreasing trend Himalayan region; Hydropower

\section{Introduction}

Nepal's vast water resources seems to electricity generation is almost dominated by hydropower and most of the hydropower systems installed are based on run-off-river (RoR) type. There are mainly two climatic factors that contribute to increased variability of river runoff: glacier retreat and change in timing and/or intensity of precipitation. Most of the hydropower projects are in critical danger from impacts of changing climatic parameters. Already, there is a general shortage of electricity during winter and dangers of spill in wet season. The large seasonal variation in electricity generation in Nepal results in acute power crisis during dry months. Before melting of snow and when there is less rainfall during winter, the discharge level in the river decreases resulting in very less production of electricity. In recent years the installed capacity (829MW) has always failed to fulfill the peak demand that has forced to power shortage of up to 18 hours a day during winter.

The year 2003/14 witnessed new records of power and energy demand, generation and import. Research on the impacts of climate change towards power generation is critically examined in this study which in turn is complex, so the present study seeks to examine optimization of power reflected by precipitation and temperature patterns in the Upper Kaligandaki River basin.

\section{The Study Area}

The Kaligandaki River is a glacier-fed antecedent river originating in the Nepal Himalayas. It runs from north to south 
in the higher Himalayan region, flows eastwardly through the lesser (or lower) Himalayan region, enters the Tarai plains of Nepal and ultimately joins the Ganges River in India. The study area, which covers a short stretch of Upper Kaligandaki River in the higher Himalaya, is located in the Trans-Himalayan region of Nepal (Figure 1). Politico-administratively the area forms part of Mustang district, one of 16 mountain districts in the country. The Upper Kaligandaki River has a catchment area of about $3500 \mathrm{~km}^{2}$ and its elevation ranges from about $2900 \mathrm{~m}$ to $8137 \mathrm{~m}$ (at Dhaulagiri Peak). The landscape of the river basin is characterized by moraine deposits and debris fans, with pine and mixed shrub-type vegetation in the river valleys.

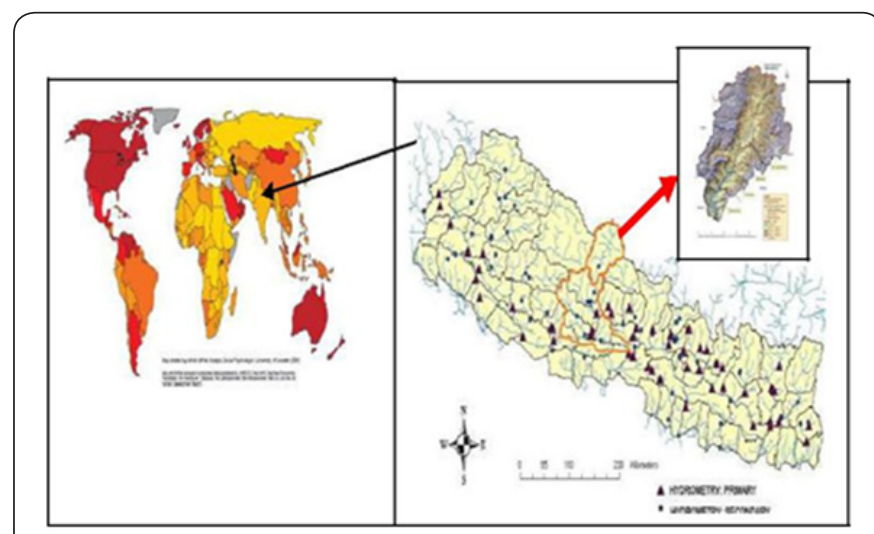

Figure 1: Location map of Nepal and Upper Kaligandaki River.

Broadly, the basin can be divided into three climatic zones:

a. A cold temperate zone up to $3000 \mathrm{~m}$;

b. An alpine zone between $3000 \mathrm{~m}$ and $4500 \mathrm{~m}$ and

c. A tundra zone above $4500 \mathrm{~m}$.

The area above $5,000 \mathrm{~m}$ is either perpetually covered with snow or consists of vertical bare rocks. The basin falls under a rain shadow and has a dry, arid climate. The area around the basin outlet has an average annual rainfall of $785 \mathrm{~mm}$ whereas the Lo-Mangthang area, which lies further north, receives only about $200 \mathrm{~mm}$ of rainfall per year [2].

The Upper Kaligandaki River basin receives most (61\%) of its precipitation during the monsoon (June to September), with winter (December to February) being the driest season (7\% of annual precipitation). During winter most of the precipitation falls as snow. The average annual flow of Upper Kaligandaki River is $25 \mathrm{~m}^{3} / \mathrm{s}$ but there is large seasonal variability, with average flows in the monsoon season (June to September) and dry season (December to February) being $54.8 \mathrm{~m}^{3} / \mathrm{s}$ and $8.6 \mathrm{~m}^{3} / \mathrm{s}$, respectively. In general, the maximum flows occur in August and the minimum flows in March. The width of the river varies from $30 \mathrm{~m}-150 \mathrm{~m}$. The gradient of the river course varies from $3 \%-16 \%$, with an average of $7 \%$. There are about 1,025 glaciers in this region (ICIMOD, 2001; 2009) and a multitude of glacier-fed streams enter the Upper Kaligandaki River. The sediment-related risk is inherent in the Kaligandaki basin due to continuous uplifting and landscape evolution [3]. A study in Lete and Ghansa (downstream of the present study area) indicated that there was an increase in suspended sediment loads by about $0.7 \%$ per year over a period of 30 years [4]. Retreating glaciers, melting of permafrost and annual fluctuation in snow cover areas in the context of rising temperatures due to accelerated global and local warming were responsible for the changing rate of sediment yields. The Major tributaries are

a) Mistri Khola in Myagdi District near Narchyang Rahughat Khola at Galeswor

b) Myagdi Khola at Beni

c) Modi Khola at Modibeni

d) Badigad Khola at Rudrabeni

e) Aandhi Khola at Mirmi

f) Ridi Khola at Ridi Bazaar

\section{Objectives of the Study}

Table 1: Identified Projects in the River Basin.

\begin{tabular}{|c|c|c|c|}
\hline Projects & Promoters & $\begin{array}{l}\text { Expected } \\
\text { Capacity } \\
\text { (MW) }\end{array}$ & Remarks \\
\hline $\begin{array}{l}\text { Kaligandaki- } \\
\text { Kowan }\end{array}$ & $\begin{array}{l}\text { Ambeswor } \\
\text { Engineering } \\
\text { Hydropower } \\
\text { Pvt.Ltd }\end{array}$ & 330 & Issued \\
\hline $\begin{array}{l}\text { Kaligandaki } \\
\text { Gorge }\end{array}$ & NECT-HIM JV & 280 & Issued \\
\hline $\begin{array}{c}\text { Upper } \\
\text { Kaligandaki }\end{array}$ & $\begin{array}{c}\text { Mata } \\
\text { Mankamana } \\
\text { Water Energy } \\
\text { Pvt. Ltd }\end{array}$ & 30 & Applied \\
\hline $\begin{array}{c}\text { Lower } \\
\text { Kaligandaki }\end{array}$ & $\begin{array}{l}\text { Delta Energy } \\
\text { Pvt Ltd }\end{array}$ & 90.47 & Applied \\
\hline $\begin{array}{l}\text { Kaligandaki } \\
\text { Upper }\end{array}$ & $\begin{array}{l}\text { Trade Link } \\
\text { Global P. Ltd. }\end{array}$ & 72.5 & Issued \\
\hline $\begin{array}{c}\text { Beni } \\
\text { Kaligandaki }\end{array}$ & $\begin{array}{l}\text { Hydro } \\
\text { Kathmandu } \\
\text { Pvt. Ltd }\end{array}$ & & Issued \\
\hline $\begin{array}{l}\text { Phalebas } \\
\text { Kaligandaki }\end{array}$ & $\begin{array}{c}\text { Mata } \\
\text { Baishnodevi } \\
\text { Hydropower } \\
\text { Pvt. Ltd. }\end{array}$ & 140 & Applied \\
\hline Kaligandaki A & NEA & 144 & Generating \\
\hline $\begin{array}{c}\text { Saligram } \\
\text { Kaligandaki }\end{array}$ & CWE & 125 & Issued \\
\hline $\begin{array}{l}\text { Kaligandaki B } \\
\text { (storage) }\end{array}$ & $\begin{array}{l}\text { NEA,s Gandak } \\
\text { Master plan }\end{array}$ & 600 & Applied \\
\hline $\begin{array}{l}\text { Kali-Sapta } \\
\text { Gandaki }\end{array}$ & $\begin{array}{l}\text { Mata Jagdamba } \\
\text { Hydropower } \\
\text { Pvt. Ltd. }\end{array}$ & 147 & Applied \\
\hline
\end{tabular}


The main objectives of this research is to identify and optimize the Kaligandaki River Basin power potentiality and possible impacts of the climate change in Kaligandaki Gorge hydropower project, some of the specific objectives are as follows;

a. To evaluate power potential in the River Basin with ROR and Storage Projects b. Quantify benefits for cost and energy

c. Evaluate impact on optimal design criteria (percentile exceedance), and cost of project

d. The impacts of Climate change in hydropower potentiality in Kaligandaki George hydropower project

e. Recommend policy implications (Table 1-3)

Table 2: Plant Capacity and Energy (Storage+ROR) (Capacity MW/Energy (GWh).

\begin{tabular}{|c|c|c|c|c|c|c|c|c|c|c|c|c|c|c|c|}
\hline \multirow{2}{*}{ Projects } & \multicolumn{3}{|c|}{ Q20 } & \multicolumn{3}{|c|}{ Q25 } & \multicolumn{3}{|c|}{ Q30 } & \multicolumn{3}{|c|}{ Q35 } & \multicolumn{3}{|c|}{ Q40 } \\
\hline & Cap & D & $\mathbf{W}$ & Cap & D & $\mathbf{W}$ & Cap & D & $\mathbf{W}$ & Cap & D & $\mathbf{W}$ & Cap & D & $\mathbf{W}$ \\
\hline KG-Koban & 330 & 164 & 1110 & 245 & 164 & 933 & 191 & 164 & 815 & 145 & 164 & 682 & 119 & 164 & 590 \\
\hline KG Gorge & 298 & 145 & 968 & 222 & 145 & 823 & 173 & 145 & 723 & 132 & 145 & 612 & 109 & 145 & 535 \\
\hline Upper KG & 31 & 15 & 105 & 24 & 15 & 91 & 19 & 15 & 80 & 14 & 15 & 67 & 12 & 15 & 58 \\
\hline Lower KG & 99 & 48 & 345 & 77 & 48 & 300 & 61 & 48 & 263 & 48 & 48 & 222 & 40 & 48 & 195 \\
\hline KG Upper & 81 & 39 & 283 & 64 & 39 & 246 & 50 & 39 & 217 & 39 & 39 & 183 & 33 & 39 & 162 \\
\hline Beni KG & 111 & 55 & 394 & 87 & 55 & 341 & 69 & 55 & 303 & 56 & 55 & 259 & 48 & 55 & 231 \\
\hline PhaleKG & 241 & 63 & 772 & 189 & 63 & 658 & 121 & 63 & 508 & 92 & 63 & 416 & 78 & 63 & 362 \\
\hline KG A & 637 & 156 & 2016 & 491 & 156 & 1696 & 334 & 156 & 1350 & 234 & 156 & 1060 & 197 & 156 & 925 \\
\hline KG B & 317 & 96 & 1018 & 236 & 96 & 838 & 164 & 96 & 679 & 119 & 96 & 547 & 95 & 96 & 455 \\
\hline Kali Sapta Gandaki & 369 & 111 & 1192 & 275 & 111 & 982 & 191 & 111 & 797 & 139 & 111 & 637 & 110 & 111 & 531 \\
\hline Total & 2514 & 892 & 8203 & 1910 & 892 & 6908 & 1373 & 892 & 5735 & 1018 & 892 & 4685 & 841 & 892 & 4044 \\
\hline
\end{tabular}

Table 3: Comparison at Optimal Level.

\begin{tabular}{|c|c|c|c|c|c|c|}
\hline \multirow{2}{*}{ Projects } & & $\begin{array}{c}\text { Storage } \\
\text { Q20 }\end{array}$ & & & & $\begin{array}{l}\text { ROR } \\
\text { Q30 }\end{array}$ \\
\hline & $\begin{array}{c}\text { Cap } \\
\text { (MW) }\end{array}$ & $\begin{array}{c}\text { Dry } \\
\text { (GWh) }\end{array}$ & $\begin{array}{c}\text { Wet } \\
\text { (GWh) }\end{array}$ & $\begin{array}{c}\text { Cap } \\
\text { (MW) }\end{array}$ & $\begin{array}{c}\text { Dry } \\
\text { (GWh) }\end{array}$ & $\begin{array}{c}\text { Wet } \\
\text { (GWh) }\end{array}$ \\
\hline $\begin{array}{c}\text { Kaligandaki } \\
\text {-Koban }\end{array}$ & 374 & 624 & 1288 & 191 & 164 & 815 \\
\hline $\begin{array}{c}\text { Kaligandaki } \\
\text {-Gorge }\end{array}$ & 298 & 457 & 968 & 173 & 145 & 723 \\
\hline $\begin{array}{c}\text { Upper } \\
\text { Kaligandaki }\end{array}$ & 31 & 41 & 106 & 19 & 15 & 80 \\
\hline $\begin{array}{c}\text { Lower } \\
\text { Kaligandaki }\end{array}$ & 99 & 113 & 345 & 61 & 48 & 263 \\
\hline $\begin{array}{c}\text { Kaligandaki } \\
\text {-Upper }\end{array}$ & 81 & 88 & 283 & 50 & 39 & 217 \\
\hline $\begin{array}{c}\text { Beni- } \\
\text { Kaligandaki }\end{array}$ & 111 & 106 & 394 & 69 & 55 & 303 \\
\hline $\begin{array}{c}\text { Phalebas } \\
\text { Kaligandaki }\end{array}$ & 241 & 95 & 772 & 121 & 63 & 508 \\
\hline $\begin{array}{c}\text { Kaligandaki } \\
-\mathrm{A}\end{array}$ & 637 & 231 & 2016 & 334 & 156 & 1350 \\
\hline $\begin{array}{c}\text { Kaligandaki } \\
\text {-Kota }\end{array}$ & 878 & 647 & 2846 & 164 & 96 & 679 \\
\hline $\begin{array}{c}\text { Kali-Sapta } \\
\text { gandaki }\end{array}$ & 369 & 271 & 1192 & 191 & 111 & 797 \\
\hline Total & 3120 & 2673 & 10204 & 1373 & 892 & 5735 \\
\hline
\end{tabular}

\section{Problem Statement}

Out of the various natural resources available in Nepal, water resource is the Prime one. The available water resources in Nepal have abundant hydro potential which can be harnessed for the development of the country, but there is a lack of reliable and accurate information about the hydro potential in Nepal. The fundamental information regarding the magnitude and distribution of the potential in the country helps in planning, formulating policies and strategies for the development of hydropower [5].

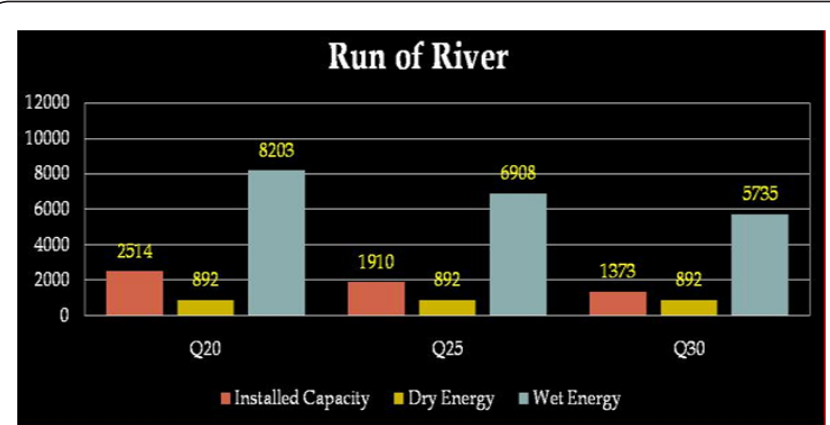

Figure 2: Run of River.

The first assessment of the theoretical hydropower potential of Nepal was done by Shrestha during his PhD research work in the former USSR about 50 years ago with limited data and analysis tools. Shrestha assessed $83,280 \mathrm{MW}$ as the theoretical hydro-potential of Nepal. The estimate was made at a time when very little river discharge and precipitation data were available (Figure 2). 
Now 154 hydrometric stations and 337 precipitation stations have been established in different parts of the country and provide more accurate hydrological data for more than 30 years. There have been advances in information technology such as remote sensing, computational tools such as geographic information system (GIS) and various hydrological modeling tools which can process and analyze the data more accurately and provide better results. Using these latest technologies, the potential can be estimated more accurately than before. However, very few studies have been done in this field after the first assessment (Figure 3).

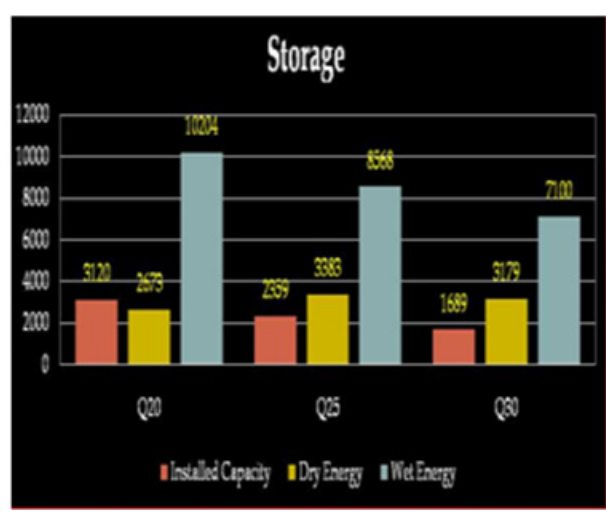

Figure 3: storage.

Albeit Nepal Electricity Authority (NEA) studied the power potential of the several rivers in the past with the assistance of foreign experts, all of these studies are rather project oriented and do not cover the entire part of the country. Therefore, necessitated reassessing the theoretical ROR hydro potential of the rivers in Nepal by using the latest computational and analysis tools to come up with the accurate and better results. By using the available data an impacts of Climate change on hydropower potential in Kaligandaki River Basin (a case study of Kaligandaki gorge hydropower project) is studied [6].

\section{Methodology}

Hydropower Potential Calculation: Hydropower potential is a function of head drop and discharge at certain flow exceedance. The theoretical ROR hydropower potential is calculated by using equation,

$$
\mathrm{P}=\rho \times \mathrm{g} \times \mathrm{Q} \times \mathrm{H}
$$

Where, $\mathrm{P}=$ Power generated in Watt $(\mathrm{W})$

$$
\begin{aligned}
& \rho=\text { Mass density of water }\left(\mathrm{kg} / \mathrm{m}^{3}\right) \\
& \mathrm{g}=\text { Acceleration due to gravity }\left(\mathrm{m} / \mathrm{s}^{2}\right) \\
& \mathrm{Q}=\text { Discharge }\left(\mathrm{m}^{3} / \mathrm{s}\right) \\
& \mathrm{H}=\text { Gross head drop }(\mathrm{m})
\end{aligned}
$$

If there are numbers of sub-basins in a given basin, the total power of the basin can be calculated by summing the potential of all sub-basins.

$$
\mathrm{P}=\sum \text { i to } \mathrm{n} \rho \times \mathrm{g} \times \mathrm{Q} \times \mathrm{H}
$$

Where, $\mathrm{i}=$ Sub-basin number $=\mathrm{i} \ldots \ldots \ldots \ldots \ldots . . . \mathrm{n}$

$\mathrm{n}=$ Number of sub-basins

$\rho=$ The mass density of water is taken as $1000 \mathrm{~kg} / \mathrm{m}^{3}$

$\mathrm{g}=$ Acceleration due to gravity $\left(\mathrm{m} / \mathrm{s}^{2}\right) \mathrm{Q}=$ Discharge

$(\mathrm{m} 3 / \mathrm{s})$

$$
\mathrm{H}=\text { Gross head drop (m) }
$$

The gross head is the elevation difference between headrace and tailrace. By estimating the head drop, $\mathrm{H}$ and discharge, $\mathrm{Q}$ of any basin, the theoretical hydro potential can be calculated. Along with Impacts of Climate Change parameters rainfall, discharge and temperature patterns have also been analyzed. This study is particularly quantitative and deductive in nature. It will incorporate study of the Kaligandaki gorge hydropower with available data to provide case study for climatic considerations in developing a hydropower.

\section{Study parameters}

To identify the controlling factors Daily rainfall data of three nearby stations (Jomsom, Lete and Ranipauwa) from 1985 to 2014 was analyzed during the study. Secondary data of the rainfall were taken from Department of Hydrology and Metrology (DHM). Optimum number of stations required for the study was based on statistical principal that a certain number of rain gauge stations are necessary to give average rainfall with a certain percentage of error. The optimum number of rain gauges (N) was obtained by the following equation:

$\mathrm{N}=(\mathrm{Cv} / \mathrm{E})$ (1) 2

Where, $\mathrm{E}$ = allowable percentage error in the estimate of basic mean rainfall

$\mathrm{Cv}=$ coefficient of variation of rainfall based on existing rain gauge station and it is determined as,

$\mathrm{Cv}=\mathrm{s} / \mathrm{Pm} \mathrm{x}_{-} 100 \%$

The standard deviation is given by:

$\mathrm{s}=\sum[(\mathrm{Pm}-\mathrm{Pi}) / \mathrm{n}-1] \frac{1}{2}$

Where, $\mathrm{Pm}=$ mean average annual rainfall values

$\mathrm{n}=$ existing number of rain gauges

$\mathrm{Pi}=$ normal annual rainfalls at existing rain gauges, for accuracy in various practical purposes; three stations were taken minimizing the error to $5 \%$.

For temperature analysis the maximum, mean and minimum monthly temperature data recorded at Jomsom for the last 30 years were analyzed. Climatologically data recorded at Lete stations from 1998 to 2014 was also analyzed during this study. Discharge data for the past 20 years (1995 to 2014) were analyzed for Kaligandaki River. This was obtained from Jomsom 
hydrological station. Monthly discharge of the river at intake of the hydropower was provided by Hydro solutions Pvt. Ltd.

\section{Scope and Limitations}

The study is carried out at the Kaligandaki gorge HP that lies at northeastern part of Myagdi district in the Western Development Region of Nepal. Scope of work of the proposed study includes following major activities:

a. Case study of Kaligandaki River to analyze changes in river flow with respect to physical and socio economic changes affecting design capacity of hydropower plant.

b. Collection of secondary data; desk study and analysis of the data.

c. Interpretation and analysis of available rainfall and temperature data for interpretation of climate change along with the analysis of water and energy demand using LEAP and WEAP (Table 4).

Table 4: \% Error Vs Optimum no. of Rain gauges.

\begin{tabular}{|c|c|}
\hline \% Error (E) & Optimumno of Raingauges (N) \\
\hline $10 \%$ & 1 \\
\hline $5 \%$ & 3 \\
\hline $4 \%$ & 4 \\
\hline
\end{tabular}

Data Analysis

\section{Precipitation}

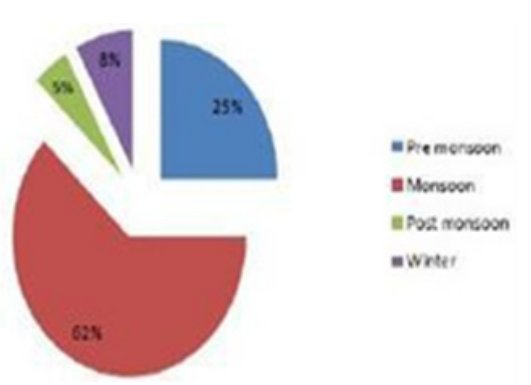

Figure 4: Seasonal rainfall distribution at Lete (1985-2014).

Nepal receives nearly $80 \%$ of annual precipitation during the months of June-September in most of the locations; Distribution of rainfall around the Kaligandaki gorge hydropower project area is not uniform either. Elevations well as exposition of mountains within the area plays major roles for uneven rainfall distribution. The 30 years of daily data available (1985-2014) for the area near the project site shows that $62 \%$ of rainfall occurs in monsoon with $25 \%$ in pre-monsoon followed by $8 \%$ and $5 \%$ in post-monsoon and winter respectively (Figure 4 ).
In a RoR project like Kaligandaki gorge project, electricity generation will vary as per precipitation patterns, which means dry seasons may require a substitute source for the demands to be met. In a reservoir based hydropower station like Kulekhani however, usage of water accumulated during monsoon can accommodate for electricity generation throughout the year. As illustrated by the graph below, precipitation around the project area peaks up from June to August and is highest during July. Winter months beginning from November and ending in January receives the lowest amount of precipitation (Figure 5).

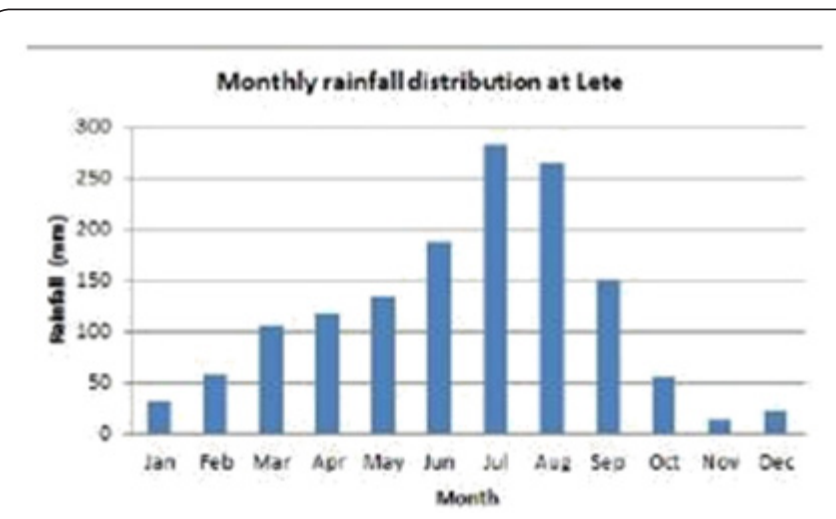

Figure 5: Monthly Rainfall Distribution of Lete (1985-2014).

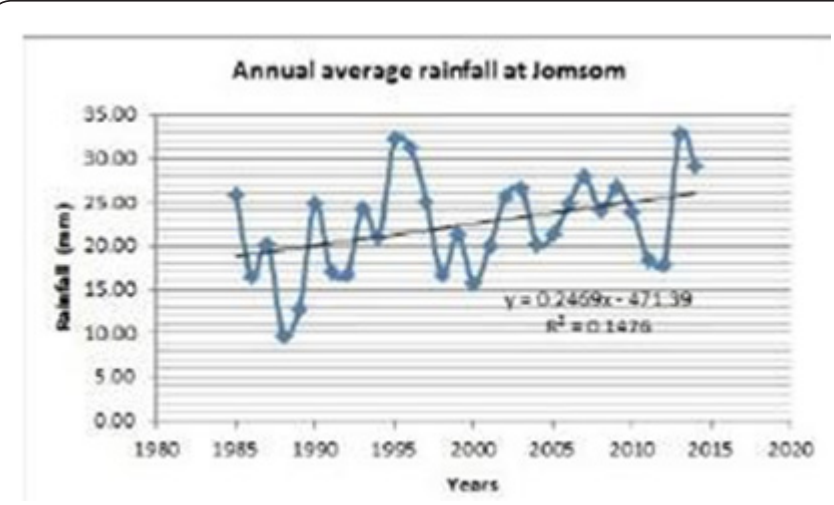

Figure 6: Annual Average Rainfall trend at Jomsom (19852014).

The monsoon normally starts in the second week of June and continues until the fourth week of September. Monsoon is the main source of rainfall in the project site similar to other regions of Nepal. The large amount of Rainfall within a short period causes flash floods, landslides, soil erosion and sedimentation in hilly and mountainous regions, and inundation of the plains areas (Figure 6). There is no significant change in annual precipitation in Nepal. This study shows that the annual average rainfall around the Kaligandaki project site is increasing at a slight rate of about $0.246 \mathrm{~m}$ and $0.284 \mathrm{~mm}$ measured at Jomsom and Lete stations respectively as shown in the plot below is concerns with slight increase in precipitation rate as seen in study based on data from Andhi Ghat Station, Mustang (Figure $7 \& 8$ ). 


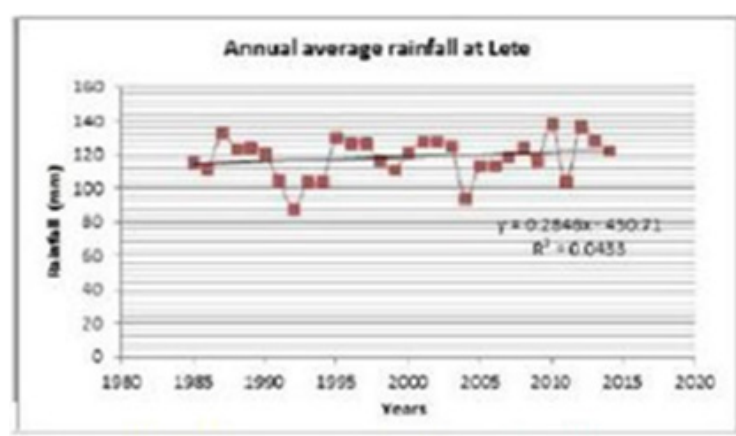

Figure 7: Annual average rainfall trend at lete (1985-2014).

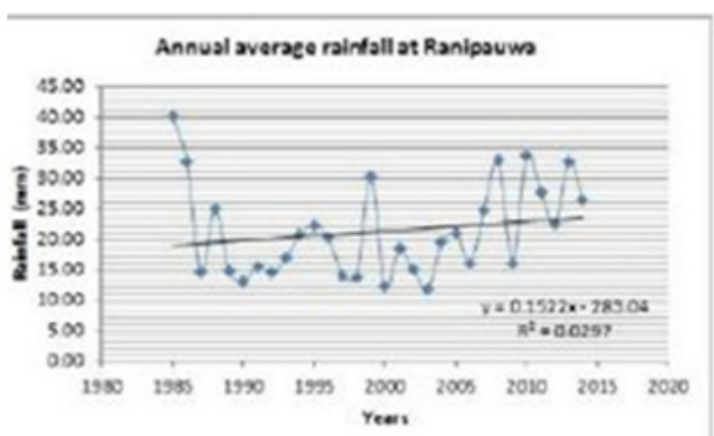

Figure 8: Annual Range Rainfall trend at Ranipauwa (19852104).

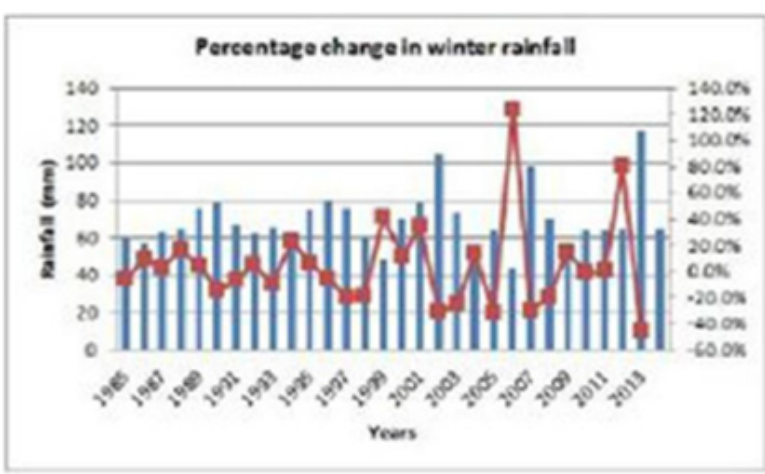

Figure 9: Percentage change in winter rainfall at lete (19852104).

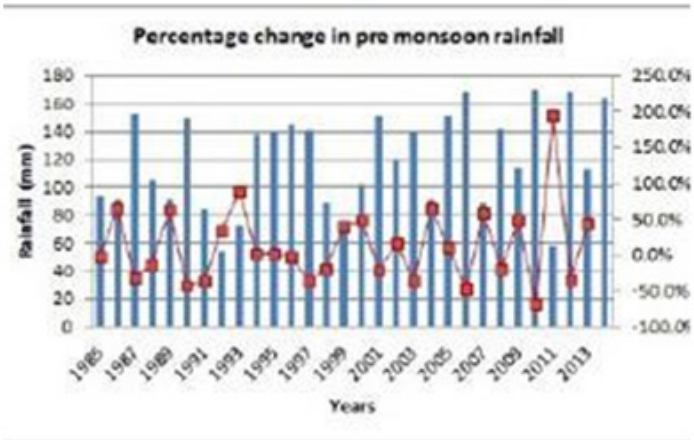

Figure 10: Percentage change in pre monsoon rainfall at lete (1985-2014).

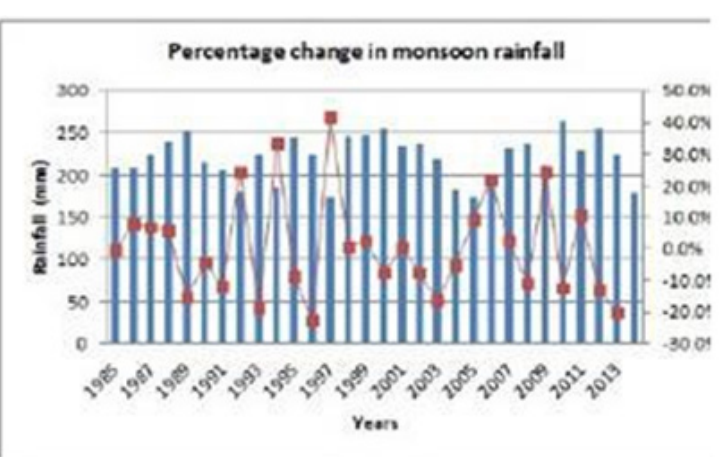

Figure 11: Percentage change in Monsoon Rainfall at lete (1985-2014).

Winter average annual rainfall distribution shows a slight increasing trend in recent years. This trend has continued in premonsoon and monsoon which provides for the annual increase in rainfall as mentioned earlier. There is a slight decrease in post monsoon rainfall (Figure 9-11).

\section{Temperature}

Annual temperature in Nepal is reported to be increasing and the impacts of warming have already been observed in the Himalayan glaciers [7]. Annual mean temperature in Nepal has increased steadily at a linear rate of $0.4 \mathrm{C}$ per decade from 1975 to 2005 [6]. Data collected from Jomsom meteorological station for 1985 to 2014 shows an increment in annual maximum, minimum and mean temperatures (Figure 12).

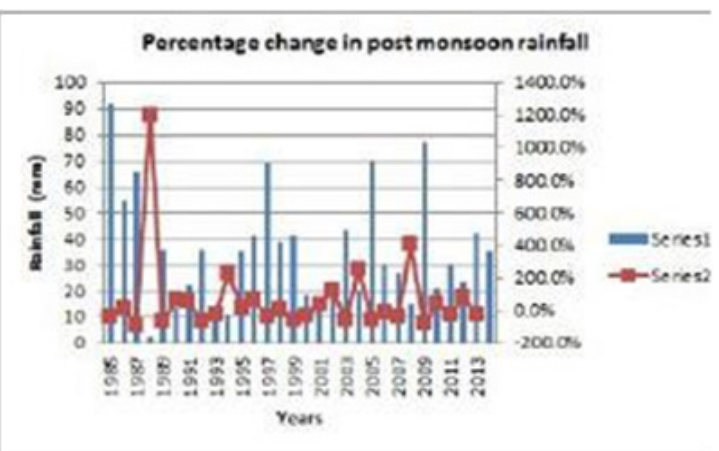

Figure 12: Percentage change in post monsoon Rainfall.

\section{Discharge}

Analysis of the available data from 1995 to 2013 shows that the average flow of $86 \mathrm{~m}^{3} / \mathrm{s}$ in 1995 has gradually decreased to $18.4 \mathrm{~m}^{3} / \mathrm{s}$ coming into 2014 . It has been shown that the flow of the Kaligandaki River at 3 station are analyzed, it indicated that the discharge is slightly decreasing order, therefore power potentiality will also in decreasing order.

Analyzing the yearly mean flow, 1998 was the maximum with a mean average flow of $213 \mathrm{~m}^{3} / \mathrm{s}$ and 2002 was the minimum with $15.1 \mathrm{~m} 3 / \mathrm{s}$. Though precipitation data shows slight increase in rainfall, the decrease in discharge may be credited to decrement 


\section{Fisheries and Oceanography Open Access Journal}

of melt from glacier. Monthly discharge measured at the intake of the planned hydropower shows increase in discharge during the monsoon i.e. July and August [8]. Annual average flow is seen at intake is around $40 \mathrm{~m} 3 / \mathrm{s}$ which concerns relatively with the data obtained from DHM (Figure 13-16).
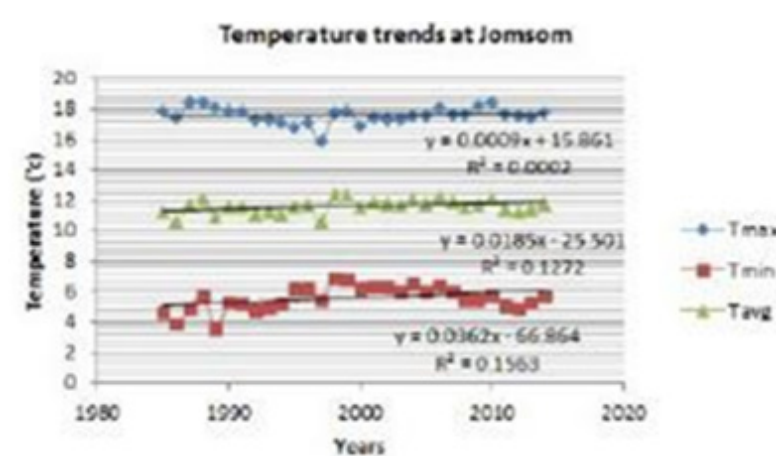

Figure 13: Annual temperature Trend in Jomsom (1985-2014).

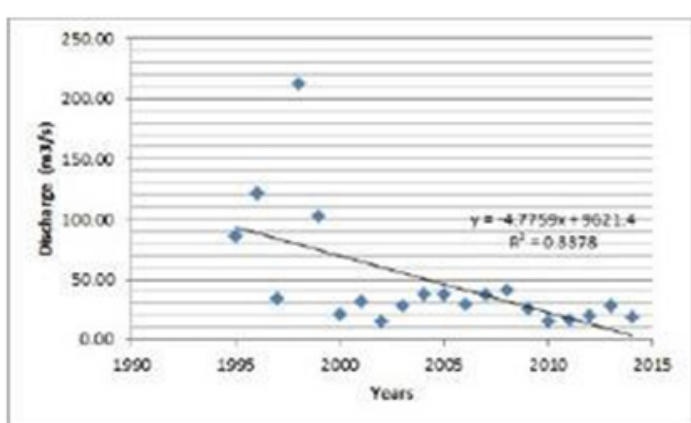

Figure 14: Annual Averege Discharge at Kaligandaki River at Jomsom (1985-2014).

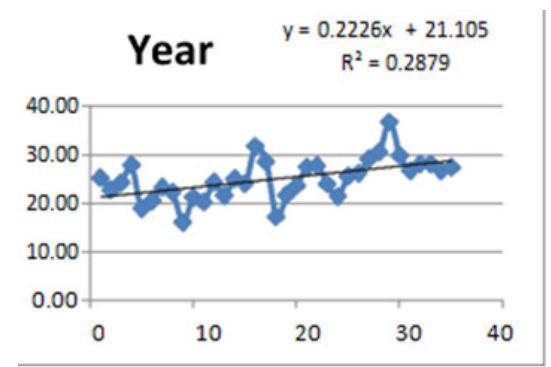

Figure 15: Annual discharge and Trend at Kaligandaki- Syang.

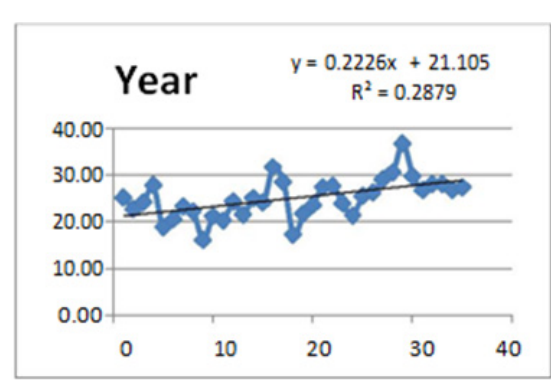

Figure 16: Annual discharge and Trend at Kaligandaki-Modi.
The zone of impact of the Kaligandaki Gorge Hydropower includes 4 VDC's of Mustang, Lete, Kunjo, Dana and Narchang. Water usage in the area is mainly dominated by agricultural and domestic purposes. There is also consumption in commercial sector but due to unavailability of exact figures, we have only taken first two sectors as computing for water usage (Figure 1719).

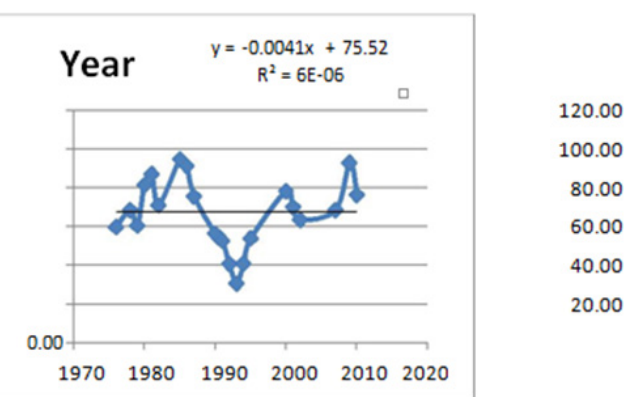

Figure 17: Annual discharge and Trend at Kaligandaki-Tatopani.

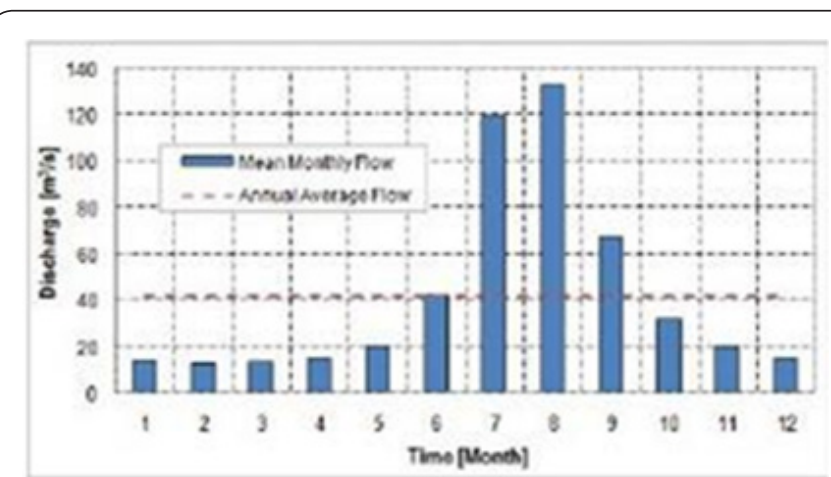

Figure 18: Monthly discharge measured at Intake (2001-2007).

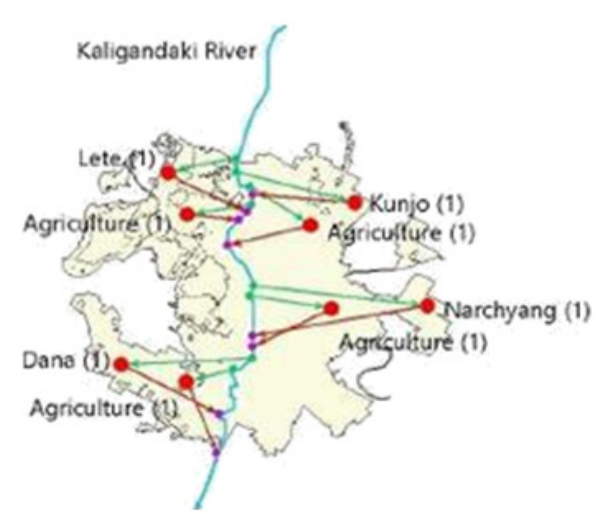

Figure 19: Schematic of demands at variousVDC's witin the zone of impact.

\section{Conclusion}

Climate change affects the dependability of hydro resources and hence the changing climatic parameters are an unavoidable factor in the forecasting system of hydropower projects. Some generalizations drawn for the study area are as follows: 
a. An increasing trend of temperature is seen around the study area.

b. Though there is a general increasing trend in precipitation, shift of the fall seasons can in-crease the hydrological impacts and challenges.

c. Storage upstream gives optimum flows in dry season to downstream projects

d. The installed capacity with storage projects increase considerably compared to ROR

e. Due to storage projects, dry energy in entirety increases by up to 3 times

f. Based on the results mentioned above, transmission line must be planned to evacuate the additional power.

g. Cost of projects decreases dramatically when rivers are planned with storage options.

h. Policies to promote storage where possible are essential to optimize Nepal's hydro resources.

i. Policies for pricing, safety R\&R etc. also need to be effective.

\section{Recommendation}

Integration of Climate change impact assessment in integrating hydropower planning is imperative and major issues for the effective planning and management of the power systems in our country. The following are the some recommendations for hydropower planners, policy makers, and other concerned agencies for coping with climate change and planning accordingly for the management of the ongoing power deficiency.

I. The rainfall distribution around the region is very uneven and basin has insufficient rain-gauge network, discharge and rainfall recording network should be increased for intensity data that are most essential for hydrologic models and other detail hydrological study.

II. Since the data analysis shows that hydrology is changing, the design capacity of the hydro system should be revised. In the long run, sufficient water may not be available; water storage in damp should be a good method to control the how of the river.

III. Only a basic modeling has been done during this project. Creation of scenarios is a potential analytical tool to predict and assess the optimization needs of subsequent demand increment as seen from demand forecasts.

\section{References}

1. Baidya SK, Shrestha ML, Sheikh MM (2008) Trends in daily climatic extremes of Temperature and precipitation in Nepal. Journal Hydrology and Meteorology (Nepal). 5(1): 38-51.

2. DHM (2008) Stream Flow Summary (1962-2006). Department of Hydrology and Meteorology (DHM), GON of Nepal. Lower Mustang Region of Nepal.

3. Adhikari BR, Wagreich M (2008) Palustrine Limestone in the sedimentary succession of the Cenozoic Thakkhola-Mustang Graben (Central Nepal). Journal of Alpine Geology 49: 1-127.

4. Bhusal JK, Bhim PS (2015) Effect of climate change on suspended sediment load in the Himalayan basin: A case study of Upper Kaligandaki River. Journal of Hydrology(NZ) 54(1): 1-10.

5. Tri Ratna B, Samanta A, Bhakta BA (2011) Changing Climatic parameters and its possible impacts on Hydropower generations in Nepal (A case study on Gandaki River Basin). Journal of IOE 8(1-2): 160-173.

6. NEA (2009) Hydropower Projects in Nepal. Technical report, Nepal Electricity Authority, Nepal.

7. Ganesh B (2011) The Kaligandaki-all about mount Everest and Nepal.

8. Integration of Climate Change Impact Parameters in Hydropower Planning in Nepal: A Case Study of Kaligandaki Gorge HP. pp. 211-217.

\section{Your next submission with Juniper Publishers will reach you the below assets}

- Quality Editorial service

- Swift Peer Review

- Reprints availability

- E-prints Service

- Manuscript Podcast for convenient understanding

- Global attainment for your research

- Manuscript accessibility in different formats

( Pdf, E-pub, Full Text, Audio)

- Unceasing customer service

Track the below URL for one-step submission https://juniperpublishers.com/online-submission.php 